Article

\title{
Are Future School Teachers Qualified to Teach Flood Risk? An Approach from the Geography Discipline in the Context of Climate Change
}

\author{
Álvaro-Francisco Morote ${ }^{1, *(1)}$, María Hernández ${ }^{2}\left[\right.$ and Jorge Olcina ${ }^{2}(\mathbb{0}$ \\ 1 Department of Experimental and Social Sciences Education, University of Valencia, 46022 Valencia, Spain \\ 2 Department of Regional Geographical Analysis and Physical Geography, University of Alicante, \\ 03690 Alicante, Spain; maria.hernandez@ua.es (M.H.); jorge.olcina@ua.es (J.O.) \\ * Correspondence: alvaro.morote@uv.es
}

Citation: Morote, Á.-F.;

Hernández, M.; Olcina, J. Are Future School Teachers Qualified to Teach Flood Risk? An Approach from the Geography Discipline in the Context of Climate Change. Sustainability 2021, 13, 8560. https://doi.org/ $10.3390 /$ su13158560

Academic Editors: José Gutiérrez -Pérez, Pablo Angel Meira Cartea, Edgar Gonzalez-Gaudiano,

Michael Sato and Isabel Cristina de Moura Carvalho

Received: 9 July 2021

Accepted: 29 July 2021

Published: 31 July 2021

Publisher's Note: MDPI stays neutral with regard to jurisdictional claims in published maps and institutional affiliations.

Copyright: (c) 2021 by the authors. Licensee MDPI, Basel, Switzerland. This article is an open access article distributed under the terms and conditions of the Creative Commons Attribution (CC BY) license (https:/ / creativecommons.org/licenses/by/ $4.0 /)$.

\begin{abstract}
The aims of this research, based on a case study (trainee teachers of Primary degree and Secondary Education-MAES of the University of Valencia, Spain), are to analyse the students' memories and perceptions of their training about floods; to examine the interest in teaching these contents in Social Science and/or Geography classes; and to analyse their proposals to improve teacher training. Methodologically, a questionnaire was distributed among 204 future teachers. The results indicate that the majority, in both groups, (degree and MAES) consider themselves to have a medium level of preparedness to teach these contents to schoolchildren (value of 3): $47.0 \%$ of the degree students and $47.4 \%$ of the MAES students. In both groups, the majority $(89.2 \%$ degree; $57.9 \%$ MAES) indicate that they had not received training in the university or if they had, it had been insufficient. The study reveals that both those who have received training and those who have not believe themselves to have a similar level of preparedness. As the results of this study show, there is still a lot of ground to be covered in the field of education so that it may become an essential tool to generate a society that is more resilient to climate change.
\end{abstract}

Keywords: floods; teaching; education; Social Sciences; Geography

\section{Introduction}

In recent decades, in the European Mediterranean region, the risk of flooding has increased due to the rise in both the exposure and vulnerability of the population [1]. To this we should add the effects of climate change, which, according to the Intergovernmental Panel on Climate Change [2], will cause an increase in the frequency and intensity of heavy rains. As explained by Mann et al. [3], Muñoz et al. [4], Serrano [5] and Woolings [6], this is a well-known and verified fact in this region. In the Iberian Peninsula (within which the area of study, the Region of Valencia, is located), a change in rainfall patterns has been observed (except on the Cantabrian coast) [7]. There has also been an alteration in the seasonality of rainfall since the 1980s. This process has been more acute in the Eastern half of the peninsula where there has been a decrease in rainfall in spring and an increase in the autumn months [8]. Finally, there has been an increase in the frequency of these extreme atmospheric events related to wavelike patterns of atmospheric circulation in the upper layers of the atmosphere and an increase from the 1990s of Isolated Depression at High Levels (DANAs) [4].

Floods constitute one of the natural hazards that cause the most casualties and deaths in Spain, Europe and the world. In 2019, 5110 people died due to floods worldwide [9]. Furthermore, according to the forecasts, it is estimated that in 2050, annual flood victims could amount to 300,000 and as many as 390,000 from the 2080s [10]. The EM-DAT (2021) [11] reports that between 2000 and 2020, 1933 human lives were lost in Europe due to 400 flood events and almost 6.8 million people were affected. In Spain, fatalities caused 
by floods amounted to 20 people in 2019 [12], which represents $20 \%$ of total fatalities in this year due to extreme natural events. For the period 1995-2015, Olcina [13] calculates a total of 526 deaths in this country. This problem is acknowledged by Spain's Ministry for Ecological Transition [14], which states that floods are the natural risk that cause the greatest damage in Spain both on an economic level and in terms of human lives.

In Spain, the expansion of built-up areas, particularly in the coastal areas of the Mediterranean region, has been a determining factor in the increase in flood risk over the last few decades [1]. According to Olcina [13], in Spain two million people live in areas of high flood risk and the Mediterranean area is the region hardest hit. In this area, where the Region of Valencia is located (the study area), according to the Action Plan of the Territorial Action for Flood Risk Prevention [15], approximately 600,000 inhabitants (12\% of the population) reside in areas at risk of flooding. Of this population, almost a quarter of a million people reside in low risk places, but around 30,000 live in areas with a high risk.

According to the Joint Research Centre [16], natural risk management has undergone significant changes over the last two decades in developed countries [17]. Parker [18] argues that, in previous decades, the main measure to reduce flood risk was the construction of hydraulic works to guarantee the level of security in the affected areas. These actions led to overconfidence in the engineering works and the maintenance and development of inappropriate actions that increased exposure and vulnerability [19]. Since 2000, actions aimed at decreasing hazards have given way to measures to reduce vulnerability and exposure [20]. These are based on land management uses, risk mapping, and the construction of "soft" infrastructures that are more respectful with the environment [21]. Nevertheless, according to Morote and Olcina [22], instruction in schools (a non-structural action) is largely overlooked. In this sense, in developed countries, it is considered essential to train future citizens in issues related to science [23], but also in connection with their daily lives [19].

The above described situations show that this phenomenon is a social problem that has an enormous impact and is highly relevant in terms of both scientific content and teaching methods [24]. If these climate change scenarios become a reality (see for example the floods in central Europe and Asia in July 2021), there will be an urgent need for a more aware society that is educated in and adapted to these phenomena in which school education should form a key pillar $[19,20,25]$. Therefore, in recent years, different authors have expressed the importance of the educational factor for reducing risk and adapting to climate change [26-28].

The need for rigorous teaching in atmospheric risks has been endorsed by the United Nations with its promotion of education in climate change and associated extreme weather events as a basic action to achieve the so-called Sustainable Development Goals (SDG) (2030 Agenda) [29]. Specifically, climate change is addressed in Objective 13 ("Climate Action") which pursues the following goals in relation to risk: (1) strengthen resilience and adaptive capacity to climate-related hazards and disasters in all countries; (2) integrate climate change measures into national policies, strategies and planning; and (3) improve education, awareness-raising and human and institutional capacity on climate change mitigation, adaptation, impact reduction and early warning. Furthermore, in its Fifth Report, the IPCC [10] referred to the role of education in adapting society to climate change in order to increase its resilience.

For this reason, in Spain, addressing these topics in the classrooms and in teacher training should be a priority, as established in the current curricula. For example, for the case of Primary Education (Royal Decree 126/2014, of 28 February) in the field of Social Science, these contents should be included in Block 2 "The world in which we live". In Obligatory Secondary Education (Royal Decree 1105/2014, of 26 December), in the subject of Geography, these contents are included in the First Cycle of ESO (Compulsory Secondary Education) (Block 1 "The physical environment") and in the second year of Baccalaureate in Block 3 ("Climate diversity and vegetation") and Block 4 ("Hydrography"). 
With regard to the studies published in the field education on flood risk, in recent years there has been a significant increase in scientific production on an international level. For example, we can refer to: the studies carried out in Asia on the implementation and development of educational plans for adapting to floods [30]; studies on social representations of the students [31]; the evaluation of the resilience and prevention measures in schools to address this phenomenon [32-34]; the evaluation of the effectiveness of drills [35]; educational programmes to improve training on flood risk [36]; or the analysis of experiences of these disasters in the field of education [37,38]. Worth mentioning are the studies carried out in the USA on the design of educational programmes that include flood risk [39,40]. In Europe, noteworthy studies have been conducted in the United Kingdom [41,42], the Netherlands [43], Poland [44], Slovenia [45] and Romania [46]. In Africa, Mudavanhu [47] has analysed the risk of flood and education.

In Spain, research on this subject matter has been principally carried out in the field of Natural Sciences [48-50]. These types of studies related to Geography and/or Social Sciences teaching are scarce and recent [51]. With respect to the Mediterranean region and flood risk, studies have been carried out on the social representations of the future Primary School teachers $[19,20,24]$ and educational proposals $[52,53]$.

Understanding the social representations that future teachers have of flooding is a priority action for generating changes in their behaviour and, therefore, that of their future students [19]. For this reason, the aims of this research, based on a case study (trainee teachers of Primary and Secondary Education, Master's degree in Secondary Education Training, MAES of the University of Valencia, Spain), are: to analyse the students' memories and perceptions of their training about floods (objectives 1 and 2); to examine the interest that future teachers have in teaching these contents in Social Science and/or Geography classes (objective 3); and to analyse their proposals to improve teacher training in flood risk at the university stage (objective 4 ).

The starting hypothesis is that the participants consider themselves to be underprepared to teach this topic in class. It is expected that they express a high level of interest in teaching this topic in the classroom. With respect to their proposals for improvement, we would expect the responses to be related to activities based on drills and talks by experts on topics not covered in the school and university curricula. This would highlight that the future teachers regard this topic as something outside of the school context despite its considerable repercussion on society and the role that the education factor can play in the training of the youngest cohorts. Regarding the groups analysed, there should be differences between them due to the influence of the disciplines in which they are trained, particularly those students from the MAES, as they are graduates of History, Art History and Geography.

\section{Methods}

\subsection{Design of the Research}

This study is based on a mixed correlational and exploratory study (non-experimental). It has a transversal design, as the information analysed was gathered at a specific moment (the academic years of 2019-2020 and 2020-2021) and refers to a case study (future teachers): students of the Primary Education Teacher degree and Master's degree in Secondary Education Training (MAES) of the University of Valencia (Spain).

\subsection{Context and Respondents}

With regard to the context and the respondents, the selection procedure was conducted through non-probability sampling (availability or convenience sampling). Two groups from the fourth year of the Primary Education Teacher degree (Faculty of Teaching Training) were selected (189 students enrolled). These participants took the subject of "Didactics of Social Sciences: applied aspects" (code 33651; academic years 2019-2020 and 2020-2021). One group of the MAES was selected (42 students enrolled in the Geography and History specialisation). These participants were registered in the subject of "Teaching and learning 
of Geography" (code 40518; academic year 2020-2021). These are the only two subjects that contain geographic content in these studies.

In the degree, with respect to the representativeness of the sample and taking into account the total number of students enrolled $(n=189)$, a minimum of 148 students would be required to obtain a representative sample so as to achieve a confidence interval of $99 \%$ and a margin of error of $5 \%$. The total number of respondents was 166 , so a representative number was achieved. With respect to the MAES (42 students enrolled), the minimum of participants should be 38 for a $95 \%$ confidence level and a 5\% margin of error. The total number of participants in this group was 38. As a result, the total number of students participating in the study was 204.

With respect to the socio-demographic characteristics, in the degree it should be noted that the majority of the respondents were women $(72.3 \% ; n=120)$. These data are within the standard ranges of the students of the Faculty of Teaching Training, as the percentage of women is $79.5 \%$ [54]. With regard to age, the average is 21.6. In relation to the MAES, women represent $50.0 \%(n=19)$ and the average age is 26.9 . An added and distinctive feature of the MAES group is the training (degree) they have undertaken. In this sense, it is worth highlighting the small number of students with a Geography degree $(5.3 \% ; n=2)$. This is important to note because the subject under study (floods) is studied in the field of geographic science. The largest number of students of the MAES comes from History $(47.4 \% ; n=18)$ and Art History $(36.8 \% ; n=14)$ degrees. Finally, a fourth typology includes "other degrees" (Marketing, Law, Sociology) $(7.9 \% ; n=3)$.

\subsection{Questionnaire and Data Analysis}

The instrument designed to carry out the research is based on a questionnaire to obtain the data needed to achieve the aims proposed. This questionnaire was validated and used in other studies [19,20]. For the purposes of this research, we adapted certain questions regarding Secondary Education and the postgraduate stage. The questionnaire was divided into six sections with a total of 31 items: (1) social characteristics; (2) the flood risk in your village; (3) flooding events in the educational centre- the route from home to school/high school; (4) training on the flood risk in school and university years; (5) the perception of the flood risk assertion; and (6) teacher training on flood risk. For this study (in accordance with the aims proposed), the results obtained in parts 4 (items 17, 28 and 29) and 6 (items 24-27 and 30) were used (see Table 1).

Table 1. Items of the questionnaire used for this research.

\begin{tabular}{|c|c|}
\hline \multicolumn{2}{|c|}{ Part 4. Future Teachers' Memories of Their Training about Floods in School and University Years } \\
\hline Item $\left(n^{\circ}\right)$ & Response Type/Variable \\
\hline $\begin{array}{l}\text { Item 17. During your school years, did you receive any type of } \\
\text { information about flood risk? }\end{array}$ & Closed-ended question: No (0)/Yes (1)/Do not know / No answer (2) \\
\hline $\begin{array}{l}\text { Item } 28 . \text { Have you previously received any training on these contents at } \\
\text { University (during your degree)? }\end{array}$ & Closed-ended question: No (0)/Yes (1)/Do not know / No answer (2) \\
\hline $\begin{array}{l}\text { Item 29. Have you previously received any training on these contents at } \\
\text { University (during the MAES)? (question only for the MAES students). }\end{array}$ & Closed-ended question: No (0)/Yes (1)/Do not know/No answer (2) \\
\hline \multicolumn{2}{|c|}{ Part 6. Teacher's Perception about Training on Flood Risk } \\
\hline $\begin{array}{l}\text { Item } 24 \text {. As a future teacher, do you think that you are qualified to train } \\
\text { these contents? }\end{array}$ & $\begin{array}{l}\text { Likert scale (1-5): } 1 \text { is the lowest qualification and } 5 \text { the } \\
\text { highest qualification. }\end{array}$ \\
\hline Item 25. Could you explain the reason for your previous answer? & Open question. \\
\hline $\begin{array}{l}\text { Item } 26 . \text { Do you think that is interesting teach these contents in } \\
\text { the classroom? }\end{array}$ & $\begin{array}{l}\text { Likert scale (1-5): } 1 \text { is the lowest importance and } 5 \text { the } \\
\text { highest importance. }\end{array}$ \\
\hline Item 27. Could you explain the reason for your previous answer? & Open question. \\
\hline $\begin{array}{l}\text { Item } 30 . \text { What would you propose to improve your training on these } \\
\text { contents in the university stage? (for the MAES's students this refers to } \\
\text { the postgraduate) }\end{array}$ & Open question. \\
\hline
\end{tabular}


In order to assess the construct validity of the questionnaire, several procedures were carried out. First, a statistical analysis was conducted of the ordinal variables (items 24 and 26). Of these variables, it was found that there was an acceptable standard deviation as the value obtained was between $0>1$. Second, the construct was subject to the Kaiser-MeyerOlkin (KMO) validity test which indicates whether the factor analysis of the instrument is acceptable or not. The KMO test gave a positive result of 0.50 (see Table 2), which, according to other factor reliability studies, is considered to be an acceptable level [55]. Third, being a mixed questionnaire (quantitative and qualitative), the Friedman Chisquared test (Friedman's $X^{2}$ ) has been carried out. It generates a positive value of 0.105 , far from zero ( $>0.05$ ), which indicates that there is discrepancy between the variables, so the variables would not be dependent on one another [56,57]. The results obtained through these procedures render the research reliable, as in the case of other studies on the teaching of Social Sciences [58].

Table 2. Construct Validity (Kaiser-Meyer-Olkin (KMO) and Bartlett's test).

\begin{tabular}{llr}
\hline Test of Kaiser-Meyer-Olkin of suitability sampling & 0.500 \\
\hline \multirow{3}{*}{ Sphericity testing of Bartlett } & Chi-square test & 0.105 \\
\cline { 2 - 3 } & gl & 1 \\
\cline { 2 - 3 } & Sig. & 0.746 \\
\hline
\end{tabular}

Source: own elaboration.

With respect to the data analysis procedure, the program SPSS v 26 was used to carry out a statistical-descriptive analysis of frequencies and percentages. In the data analysis, when necessary, non-parametric statistics were used to test hypotheses. The Mann-Whitney (two independent samples) and Kruskal-Wallis tests (more than two independent samples) were considered suitable for non-normalised distributions to establish relations between items 24, 26 and 30 (dependent variables) with 17, 28 and 29 (independent variables). Furthermore, for the correlation analysis, the Chi-squared test was carried out for the nominal variables (items 17, 25, 28 and 30), and Spearman's RHO correlation tests were conducted for the ordinal variables (items 24 and 26). The opinions in the open responses (qualitative information) of items 25, 27 and 30 have been coded (see Tables 3-5).

Table 3. Coding of answers to item 25.

\begin{tabular}{lc}
\multicolumn{1}{c}{ Response Type } & Code \\
\hline I am not qualified & 0 \\
I have not received training & 1 \\
I have received training, but I need more information & 2 \\
I have received training and I feel qualified & 3 \\
I feel qualified because it is an easy subject to teach & 4 \\
Do not know/no answer & 5 \\
\hline
\end{tabular}

Source: own elaboration.

Table 4. Coding of answers to item 27.

\begin{tabular}{lc}
\multicolumn{1}{c}{ Response Type } & Code \\
\hline Do not know /no answer & 0 \\
To increase resilience & 1 \\
To increase awareness & 2 \\
Because it is an important issue for society & 3 \\
\hline
\end{tabular}

Source: own elaboration. 
Table 5. Coding of answers to item 30.

\begin{tabular}{lc}
\hline \multicolumn{1}{c}{ Response Type } & Code \\
\hline More information and resources & 1 \\
Do drills and talks by experts & 2 \\
Share real-life experiences & 3 \\
Specific subjects and courses on this topic & 4 \\
Understand the reason of floods & 5 \\
Viewing videos and documentaries & 6 \\
Others & 7 \\
Do not know /no answer & 8 \\
\hline
\end{tabular}

Source: own elaboration.

\subsection{Procedure}

The questionnaire was distributed in a mid-term session (first four-month period) during the last week of November (2019 and 2020) and with a response time of $20 \mathrm{~min}$. It should be also noted that the questionnaire was administered prior to the teaching of sessions related to climate and natural hazards so as not to influence the answers. Finally, the participants' anonymity was preserved during the entire procedure and confidentiality was guaranteed in writing.

\section{Results}

\subsection{Future Teachers' Memories of Their Training about Floods}

With respect to their school education (item 17), a minority of the participants of both the degree and the MAES indicate that they received training: $26.5 \%(n=44)$ of the degree course students and $23.7 \%(n=9)$ of the MAES students (see Table 6). There is a remarkable number of participants in the case of the MAES students who do not remember $(36.8 \% ; n=14)$, maybe because more time has passed since the end of their school years (more than five years). The Chi-squared test reveals that the association between these two variables (training and qualification-degree and Master's degreeMAES) is not significant (Pearson's Chi-squared $=7.790 ; p=0.020$ ). Therefore, the two variables are independent.

Table 6. Future teachers' memories on flood risk training during their school years (item 17).

\begin{tabular}{|c|c|c|c|c|c|}
\hline & & & Degree & MAES & Total \\
\hline \multirow{6}{*}{ School training } & \multirow{2}{*}{0} & $n$ & 94 & 15 & 109 \\
\hline & & $\%$ & $56.6 \%$ & $39.5 \%$ & $53.4 \%$ \\
\hline & \multirow{2}{*}{1} & $n$ & 44 & 9 & 53 \\
\hline & & $\%$ & $26.5 \%$ & $23.7 \%$ & $26.0 \%$ \\
\hline & \multirow{2}{*}{2} & $n$ & 28 & 14 & 42 \\
\hline & & $\%$ & $16.9 \%$ & $36.8 \%$ & $20.6 \%$ \\
\hline \multirow{2}{*}{ Total } & & $n$ & 166 & 38 & 204 \\
\hline & & $\%$ & $100.0 \%$ & $100.0 \%$ & $100.0 \%$ \\
\hline
\end{tabular}

Source: survey results. Own elaboration. Note: No (0)/Yes (1)/Do not know/No answer (2).

With respect to university training (item 28), there is a noteworthy difference between those who received training and those who did not between the two groups. In this case, the academic discipline plays a relevant role, as $34.2 \%(n=13)$ of the students of the MAES received training when studying their degree. This percentage is only $6.0 \%(n=10)$ for the degree students (Figure 1). This indicates that the subject of study is more relevant for studies related to the Social Sciences (principally History and Geography). These contents are not usually taught in Education degrees as greater importance is given to teaching procedures and strategies. The Chi-squared test shows that the association between these 
two variables is significant (Pearson's Chi-squared $=25.958 ; p=0.001$ ). In other words, they are significantly related $(p<0.05)$. This indicates that the two variables are dependent on one another. Therefore, training on flood risk is influenced by the degree subject of the teachers. In any case, the data on both groups show very low values with respect to the total sample. From this, we could deduce that teachers may respond that they consider themselves to be insufficiently prepared to teach these contents to schoolchildren as we will see in the following point.

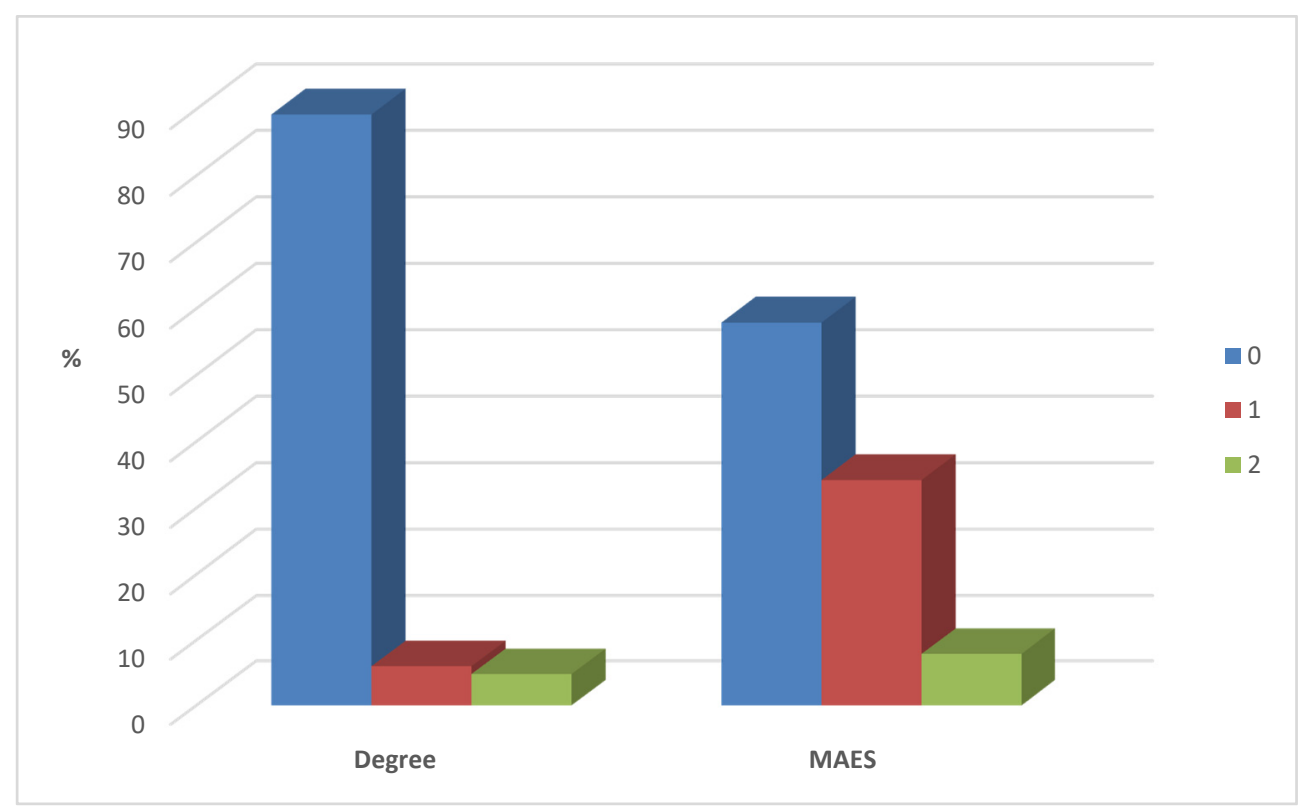

Figure 1. Future teachers' memories on flood risk training during the university education (item 28). Source: survey results. Own elaboration. Note: No (0)/Yes (1)/Do not know / No answer (2).

For the specific group of the MAES students, it is also interesting to analyse the university training received during their undergraduate degree (Geography, History and Art History). The data indicate that the geographers received training $(100.0 \% ; n=2)$, while this figure falls to $50.0 \%(n=9)$ for History graduates and $14.3 \%(n=2)$ for Art History graduates. The Chi-squared test reveals that the association between these two variables is not significant (Pearson's chi-squared $=14.171 ; p=0.028$ ). Therefore, the variables are independent. As the MAES student sample is smaller $(n=38)$ than that of the participants of the Education Degree $(n=166)$, analysis and data collection in the future will required in order to draw clearer conclusions for the MAES students.

\subsection{Are Future Teachers Qualified to Teach These Contents in the School Stage?}

After examining the education received by the participants, their degree of preparedness to teach these contents in the school stages were analysed (item 24). The results indicate that the majority, (degree and MAES) consider themselves to have a medium level of preparedness (value of 3): $47.0 \%(n=78)$ of the degree students and $47.4 \%(n=18)$ of the MAES students (see Table 7). The Mann-Whitney $U$ test is used to compare the participants who responded on their level of preparedness to teach these contents. Although the MAES students have higher values (average range of 107.47) than the degree students (average range of 101.36), the differences between the two groups are not significant $(U=2965.0$; $p=0.535$ ) (Table 8). 
Table 7. The preparation of teachers for teaching flood risk to schoolchildren (item 24).

\begin{tabular}{|c|c|c|c|c|c|}
\hline & & & Degree & MAES & Total \\
\hline \multirow{10}{*}{ Preparedness } & \multirow{2}{*}{1} & $n$ & 5 & 4 & 9 \\
\hline & & $\%$ & $3.0 \%$ & $10.5 \%$ & $4.4 \%$ \\
\hline & \multirow{2}{*}{2} & $n$ & 58 & 8 & 66 \\
\hline & & $\%$ & $34.9 \%$ & $21.1 \%$ & $32.4 \%$ \\
\hline & \multirow{2}{*}{3} & $n$ & 78 & 18 & 96 \\
\hline & & $\%$ & $47.0 \%$ & $47.4 \%$ & $47.1 \%$ \\
\hline & \multirow{2}{*}{4} & $n$ & 18 & 6 & 24 \\
\hline & & $\%$ & $10.8 \%$ & $15.8 \%$ & $11.8 \%$ \\
\hline & \multirow{2}{*}{5} & $n$ & 7 & 2 & 9 \\
\hline & & $\%$ & $4.2 \%$ & $5.3 \%$ & $4.4 \%$ \\
\hline \multirow{2}{*}{ Total } & & $n$ & 166 & 38 & 204 \\
\hline & & $\%$ & $100.0 \%$ & $100.0 \%$ & $100.0 \%$ \\
\hline
\end{tabular}

Source: survey results. Own elaboration. Note: Likert scale (1-5): 1 is the lowest qualification and 5 the highest qualification.

Table 8. Relation between preparedness (item 24) and qualification (degree and MAES).

\begin{tabular}{lr}
\hline & Preparedness \\
\hline Mann-Whitney $U$ test & 2965.000 \\
\hline Wilcoxon W test & $16,826.000$ \\
\hline$Z$ & -0.621 \\
\hline Asymptotic significance (bilateral) & 0.535 \\
\hline A. Grouping variable: Qualification & \\
\hline Source: survey results. Own elaboration. &
\end{tabular}

In relation to the preparedness of the teachers, the participants were also asked to give reasons for their answers (item 25). The results indicate that for both groups, the most frequent answers were those of Type 1 ("I have not received training") and Type 2 ("I have received training, but I need more information") (Figure 2). These data reveal that future teachers do not feel qualified to teach this topic in the classroom as together, these two responses exceed $65.0 \%$ of the total. For example, some of the Type 1 responses are: "I have never been taught anything about floods" (student no. 3 of the degree course) or "due to the lack of information about risk prevention" (student no. 12 of the MAES). With respect to the Type 2 responses: "I have received training, but I would need prior preparation" (student no. 15 of the degree course); "I would have to reinforce my understanding and acquire new knowledge" (student no. 23 of the MAES). The Chi-squared test reveals that the association between these two variables is not significant (Pearson's Chi-squared $=4.244 ; p=0.515$ ). Therefore, the variables are independent. This indicates that the qualification (degree or MAES) does not influence the response regarding preparedness.

Furthermore, item 24 (preparedness) has been related to university training in the degree (item 28). For the case of the degree group (Primary Education degree), the data indicate that there is no difference in the preparedness of those students who have received training at university and those who have not (Table 9). The Kruskal-Wallis test was used to compare the responses regarding the preparedness of the future teachers with the training that they had received during their university degree course. Even though the average range is higher for those who had received training (average range of 100.15), the differences between the categories of preparedness were not significant (Kruskal-Wallis $\mathrm{H}=1.625 ; p=0.444$ ) (see Table 10). 


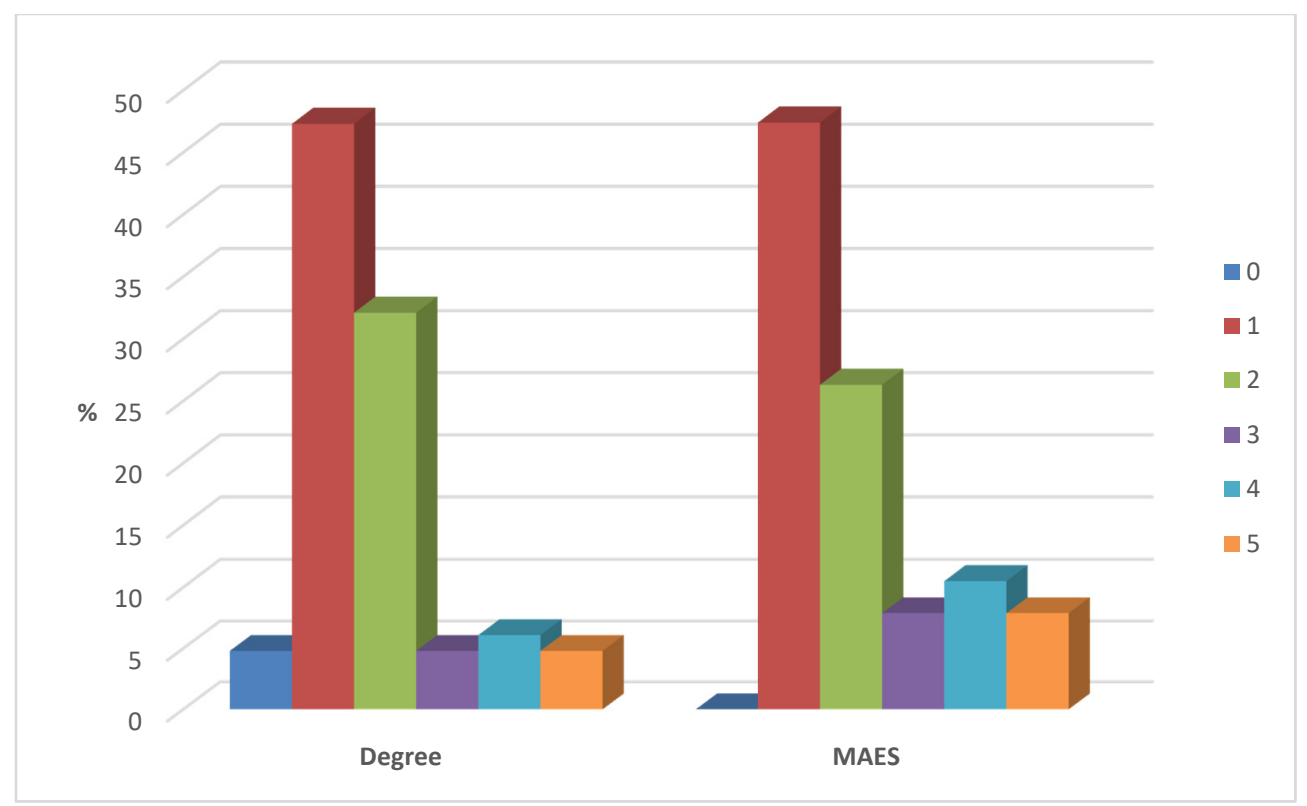

Figure 2. Reasons for the responses related to the preparation of teachers for teaching flood risk to schoolchildren (item 25). Source: survey results. Own elaboration. Note: "I am not qualified" (0); “I have not received training" (1); "I have received training, but I need more information" (2); "I have received training and I feel qualified" (3); "I feel qualified because it is an easy subject to teach" (4); "Do not know/no answer" (5).

Table 9. Relationship between preparedness (item 24) and university training during the undergraduate degree (item 28) (group of the degree in Primary Education).

\begin{tabular}{|c|c|c|c|c|c|c|}
\hline & & & \multicolumn{3}{|c|}{ University Training (in the Undergraduate Degree) } & \multirow{2}{*}{ Total } \\
\hline & & & 0 & 1 & 2 & \\
\hline \multirow{10}{*}{ Preparedness } & \multirow{2}{*}{1} & $n$ & 4 & 1 & 0 & 5 \\
\hline & & $\%$ & $2.7 \%$ & $10.0 \%$ & $0.0 \%$ & $3.0 \%$ \\
\hline & \multirow{2}{*}{2} & $n$ & 54 & 1 & 3 & 58 \\
\hline & & $\%$ & $36.5 \%$ & $10.0 \%$ & $37.5 \%$ & $34.9 \%$ \\
\hline & \multirow{2}{*}{3} & $n$ & 68 & 5 & 5 & 78 \\
\hline & & $\%$ & $45.9 \%$ & $50.0 \%$ & $62.5 \%$ & $47.0 \%$ \\
\hline & \multirow{2}{*}{4} & $n$ & 15 & 3 & 0 & 18 \\
\hline & & $\%$ & $10.1 \%$ & $30.0 \%$ & $0.0 \%$ & $10.8 \%$ \\
\hline & \multirow{2}{*}{5} & $n$ & 7 & 0 & 0 & 7 \\
\hline & & $\%$ & $4.7 \%$ & $0.0 \%$ & $0.0 \%$ & $4.2 \%$ \\
\hline \multirow{2}{*}{ Total } & & $n$ & 148 & 10 & 8 & 166 \\
\hline & & $\%$ & $100.0 \%$ & $100.0 \%$ & $100.0 \%$ & $100.0 \%$ \\
\hline
\end{tabular}

Source: survey results. Own elaboration. Note: axis of "University training (in the undergraduate degree)": No (0)/Yes (1)/Do not know/No answer (2); axis of "Preparedness": Likert scale (1-5): 1 is the lowest qualification and 5 the highest qualification.

For the case of the MAES group, a similar situation can be observed to that of the Primary Education degree students. However, one aspect should be pointed out: in the MAES two students who received training responded that they had a preparedness of 5. This was not the case for the degree group. Nevertheless, in general, the data indicate that there is no difference in the preparedness depending on whether students have received 
training at university or not (Table 11). The Kruskal-Wallis test corroborates the previous statement. The results of this test show that the differences between the categories of preparedness were not significant (Kruskal-Wallis $\mathrm{H}=3.229 ; p=0.199$ ) (see Table 12).

Table 10. Non-parametric tests of the relationship between items 24 and 28 (group of the degree in Primary Education).

\begin{tabular}{|c|c|c|c|}
\hline \multicolumn{4}{|c|}{ Ranges } \\
\hline & University Training (in the Undergraduate Degree) & $n$ & Average Range \\
\hline \multirow{4}{*}{ Preparedness } & 0 & 148 & 82.73 \\
\hline & 1 & 10 & 100.15 \\
\hline & 2 & 8 & 77.00 \\
\hline & Total & 166 & \\
\hline
\end{tabular}

\section{Kruskal-Wallis Test}

Preparedness

\begin{tabular}{lr} 
Kruskal-Wallis H & 1.625 \\
\hline gl & 2 \\
\hline Asymptotic significance & 0.444 \\
\hline
\end{tabular}

Source: survey results. Own elaboration. Note: No (0)/Yes (1)/Do not know / No answer (2).

Table 11. Relationship between preparedness (item 24) and university training during the undergraduate degree (item 28) (MAES group).

\begin{tabular}{|c|c|c|c|c|c|c|}
\hline & & & \multicolumn{3}{|c|}{ University Training (in the Undergraduate Degree) } & \multirow{2}{*}{ Total } \\
\hline & & & 0 & 1 & 2 & \\
\hline \multirow{10}{*}{ Preparedness } & \multirow{2}{*}{1} & $n$ & 3 & 1 & 0 & 4 \\
\hline & & $\%$ & $13.6 \%$ & $7.7 \%$ & $0.0 \%$ & 10.5 \\
\hline & \multirow{2}{*}{2} & $n$ & 6 & 2 & 0 & 8 \\
\hline & & $\%$ & $27.3 \%$ & $15.4 \%$ & $0.0 \%$ & $21.1 \%$ \\
\hline & \multirow{2}{*}{3} & $n$ & 10 & 6 & 2 & 18 \\
\hline & & $\%$ & $45.5 \%$ & $46.2 \%$ & $66.7 \%$ & $47.4 \%$ \\
\hline & \multirow{2}{*}{4} & $n$ & 3 & 2 & 1 & 6 \\
\hline & & $\%$ & $13.6 \%$ & $15.4 \%$ & $33.3 \%$ & $15.8 \%$ \\
\hline & \multirow{2}{*}{5} & $n$ & 0 & 2 & 0 & 2 \\
\hline & & $\%$ & $0.0 \%$ & $15.4 \%$ & $0.0 \%$ & $5.3 \%$ \\
\hline \multirow{2}{*}{ Total } & & $n$ & 22 & 13 & 3 & 38 \\
\hline & & $\%$ & $100.0 \%$ & $100.0 \%$ & $100.0 \%$ & $100.0 \%$ \\
\hline
\end{tabular}

Source: survey results. Own elaboration. Note: axis of "University training (in the undergraduate degree)": No (0)/Yes (1)/Do not know/No answer (2); axis of "Preparedness": Likert scale (1-5): 1 is the lowest qualification and 5 the highest qualification.

\subsection{Interest in Teaching the Risks of Flooding to Schoolchildren}

The next objective contemplated in this study is to analyse the interest to teach this topic to children in Primary Education (degree group) and Secondary Education (MAES group). The results obtained indicate that there is considerable interest in this topic, as the majority of the responses are concentrated in values 4 and 5 (see Figure 3). The result of the Mann-Whitney $U$ test shows that the differences between the interest categories were not significant $(\mathrm{U}=3.153 ; p=0.997)$. Therefore, the variables are independent. 
Table 12. Non-parametric tests of the relationship between items 24 and 28 (MAES group).

\begin{tabular}{llrrr}
\hline & \multicolumn{2}{c}{ Ranges } & $n$ & Average Range \\
\hline & University Training (in the Undergraduate Degree) & 22 & 17.00 \\
\hline \multirow{3}{*}{ Preparedness } & $\mathbf{0}$ & 13 & 22.35 \\
\cline { 2 - 5 } & $\mathbf{1}$ & 3 & 25.50 \\
\cline { 2 - 5 } & Total & 38 & \\
\hline
\end{tabular}

Kruskal-Wallis Test

Preparedness

Kruskal-Wallis $\mathrm{H}$

gl

Source: survey results. Own elaboration. Note: No (0)/Yes (1)/Do not know/No answer (2).

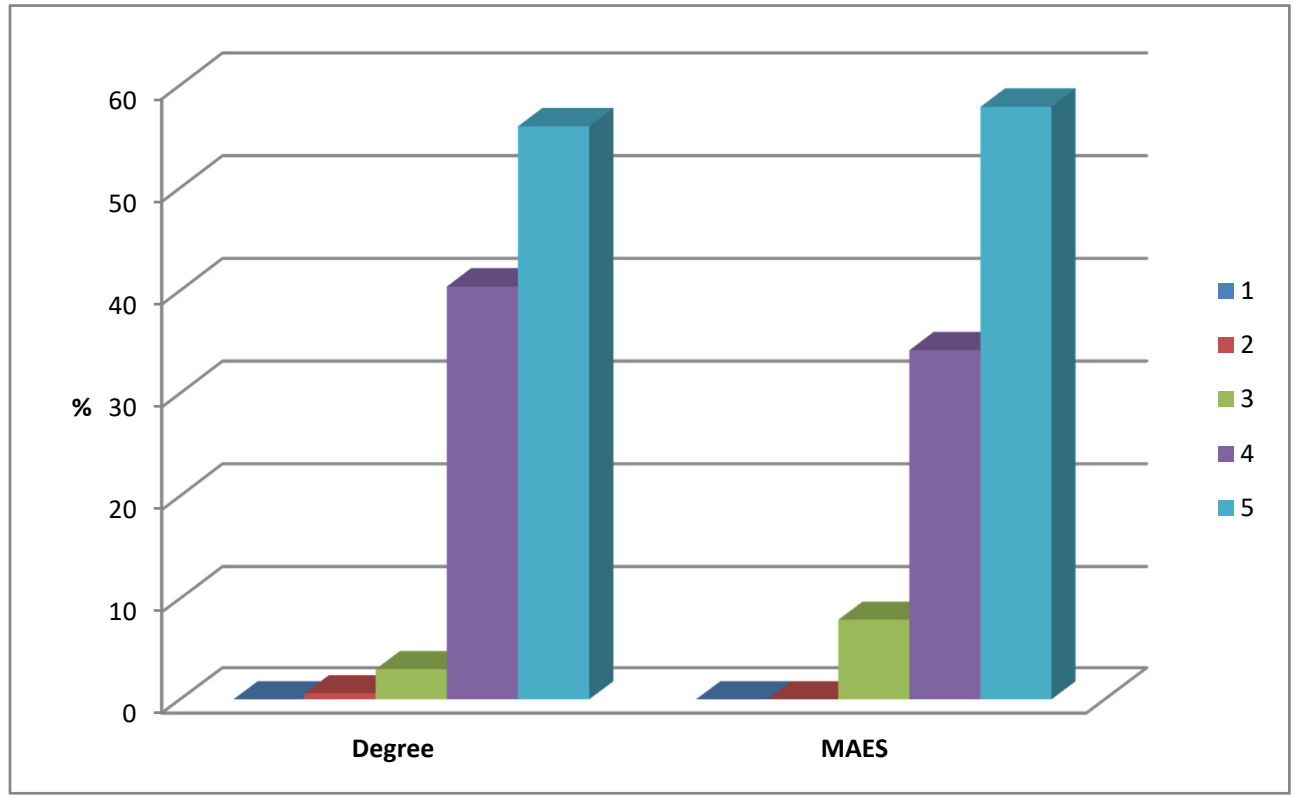

Figure 3. Interest in teaching flood risk to schoolchildren (item 26). Source: survey results. Own elaboration. Note: Likert scale (1-5): 1 is the lowest qualification and 5 the highest interest.

In relation to their interest in teaching this topic, the future teachers were also asked to give reasons for their answers (item 27). Among them, we can highlight both similar and different responses. The similar responses are related to the Type 1 reasons ("to increase resilience") and Type 2 reasons ("to increase awareness"), which together account for 50.0\% of the total (see Figure 4). Representative Type 1 responses are: "I believe it is important to be trained in this aspect. It is always important to know what to do when a risk arises" (student no. 3 of the degree course); "I believe that many cases of floods could be avoided if the correct measures are taken by the institutions/society and this should have a solid base in the teaching-learning process" (student no. 19 of the MAES). Type 2 responses included: "To raise the student's awareness of the possible risks of floods and how they can occur" (student no. 34 of the degree); "at some point the phenomenon of flooding should be taught so that the students can gain knowledge but mostly to raise their awareness. All of this should be directed at reducing the possible economic and human costs inherent in floods" (student no. 11 of the MAES). 


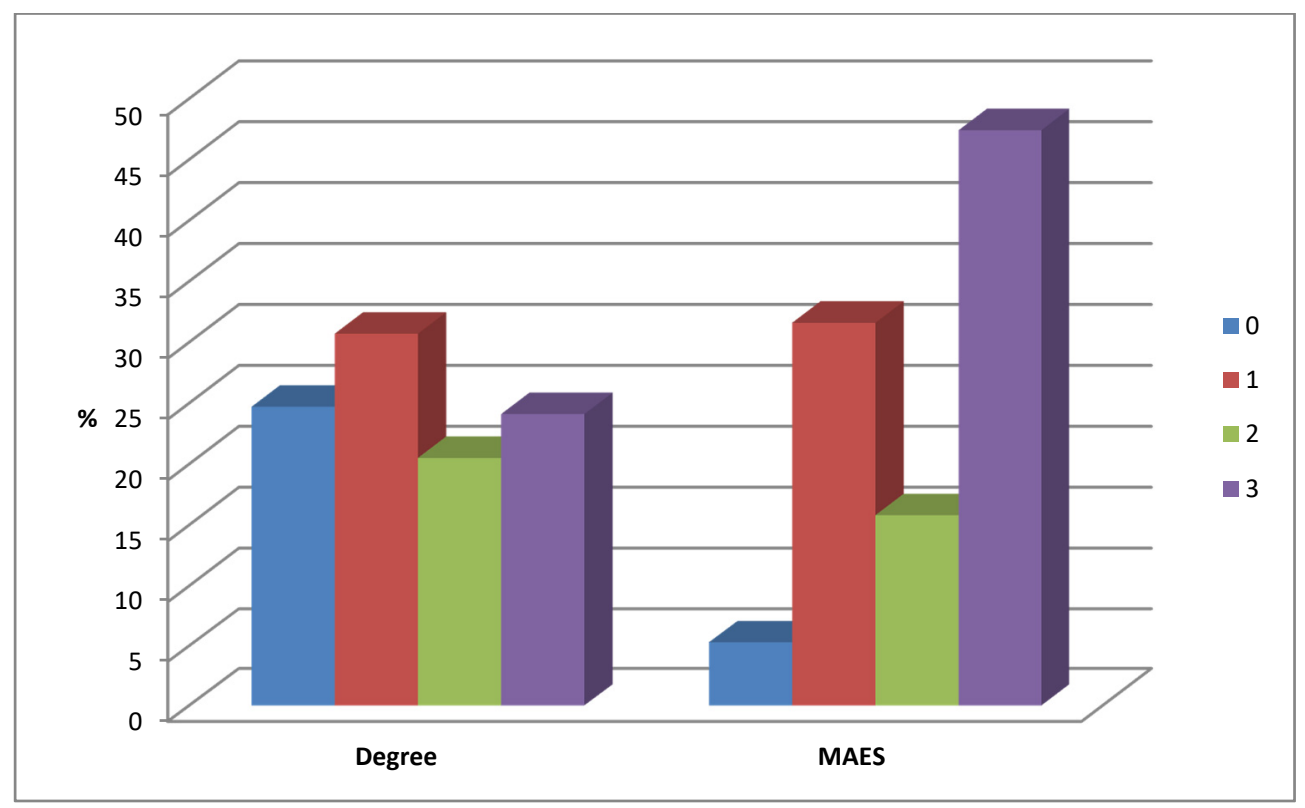

Figure 4. Reasons for the interest in teaching flood risk to schoolchildren (item 27). Source: survey results. Own elaboration. Note: "Do not know/no answer" (0); “To increase resilience" (1); "To increase awareness" (2); "Because it is an important issue for society" (3).

When comparing the two groups, differences are found for the case of the degree course, in the "no response" category $(24.7 \% ; n=41)$. In the MAES group, the differences are related to the "it is an important issue for society" (Type 3) category, which represent $47.4 \%(n=18)$. The latter response (Type 3$)$ is important as the participants give relevance to the terms of society and population: "they are phenomena that are frequently found in society and the media and have physical, economic and human effects" (student no. 22 of the MAES); "it is important to know the natural risks, particularly in areas such as Valencia where it rains a lot in a short space of time" (student no. 23 of the MAES); "it is a major issue and affects people on an economic (possible material level) social and environmental level (student no. 26 of the MAES). The result of the Chi-squared test reveals that the association between these two variables is significant (Pearson's Chi-squared $=11.786$; $p=0.008)$. Therefore, the two variables are dependent, that is, the reasons for the interest shown depend on the type of group (degree or MAES) (Table 13).

Table 13. Relationship between reasons for interest (item 27) and the qualification (degree and MAES).

\begin{tabular}{lccrr}
\hline \multicolumn{4}{c}{ Chi-Squared Test } & \\
\hline & Value & df & Asymptotic Significance (Bilateral) \\
\hline Pearson's chi-squared & 11.786 & 3 & 0.008 \\
\hline Likelihood ratio & 12.963 & 3 & 0.005 \\
\hline Linear by linear association & 9.341 & 1 & 0.002 \\
\hline Number of valid cases & 204 & & \\
\hline
\end{tabular}

Source: survey results. Own elaboration.

An interesting relationship between variables can be found between interest (item 26) and preparedness (item 24). As the data obtained from the interest variable are high in both groups, (degree and MAES), the Spearman RHO test confirms that there is no direct relationship between these two variables. In other words, not being prepared does not mean that the interest in teaching these contents is low: $\mathrm{RHO}=0.083$ (degree); $\mathrm{RHO}=0.065$ (MAES) (Table 14). 
Table 14. Correlation between interest (item 26) and preparedness (item 24).

\begin{tabular}{|c|c|c|c|c|}
\hline \multicolumn{5}{|c|}{ Degree } \\
\hline & & & Interest & Preparedness \\
\hline \multirow{6}{*}{ Spearman Rho } & \multirow{3}{*}{ Interest } & Correlation coefficient & 1.000 & 0.083 \\
\hline & & Sig. (bilateral) & & 0.289 \\
\hline & & $\mathrm{N}$ & 166 & 166 \\
\hline & \multirow{3}{*}{ Preparedness } & Correlation coefficient & 0.083 & 1.000 \\
\hline & & Sig. (bilateral) & 0.289 & \\
\hline & & $\mathrm{N}$ & 166 & 166 \\
\hline \multicolumn{5}{|c|}{ MAES } \\
\hline & & & Interest & Preparedness \\
\hline \multirow{6}{*}{ Spearman Rho } & \multirow{3}{*}{ Interest } & Correlation coefficient & 1.000 & 0.065 \\
\hline & & Sig. (bilateral) & & 0.698 \\
\hline & & $\mathrm{N}$ & 38 & 38 \\
\hline & \multirow{3}{*}{ Preparedness } & Correlation coefficient & 0.065 & 1.000 \\
\hline & & Sig. (bilateral) & 0.698 & \\
\hline & & $\mathrm{N}$ & 38 & 38 \\
\hline
\end{tabular}

Source: survey results. Own elaboration.

\subsection{What Do the Future Teachers Propose to Improve Their Preparedness for Teaching Flood Risk?}

The last objective of this research is to analyse the proposals of the future teachers to improve their training and preparedness for teaching flood risk (item 30). Among the students of the degree course, we can highlight the Type 1 proposal "More information and resources" $(56.0 \% ; n=93)$. This percentage is slightly lower in the MAES group (39.5\%; $n=15$ ) (see Figure 5). Some of these proposals are: "for our teachers to provide us with resources and show us how to teach them to the children" (student no. 8 of the degree); "more time, information and resources to work with these contents in the practical period in the Practicum centres" (student no. 36 of the MAES).

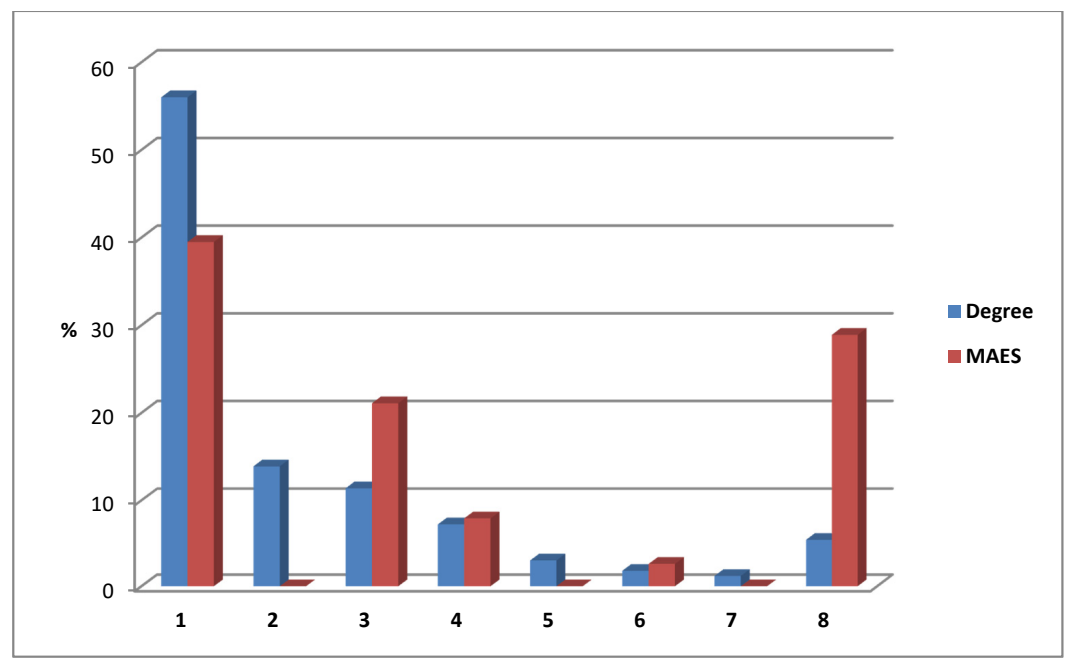

Figure 5. Proposals of the future teachers to improve their training on flood risk at the university stage (item 30). Source: survey results. Own elaboration. Note: "More information and resources" (1); "Do drills and talks by experts" (2); "Share real-life experiences" (3); "Specific subjects and courses on this topic" (4); "Understand the reason of floods" (5); "Viewing videos and documentaries" (6); "Others" (7); "Do not know/no answer" (8). 
Unlike the students of the degree course, those of the Master's degree suggest two types of proposals: "share real-life experiences" (Type 3) $(21.1 \% ; n=8)$ and those who replied "Do not know/no answer", that is, they did not have any proposals to offer (Type 8) $(28.9 \% ; n=11)$. Some of the Type 3 responses are: "To see examples and real floods occurring in the Region of Valencia" (student no. 21 of the MAES). It is also noteworthy that the degree group was the only group to propose the improvement of their training through drills and talks (Type 2) $(13.9 \% ; n=23)$. As we will see in the Discussions section, this is highly characteristic of this type of student. Some of these proposals are: "talks by experts" (student no. 14 and 15 of the degree course); "workshops and courses" (student no. 19 of the degree). The result of the Chi-squared test shows that the association between these two variables (proposals and qualification) is significant (Pearson's Chi-squared $=28.205$; $p=0.001$ ). Therefore, they are dependent variables. That is, the qualification being studied by the participants influences the type of proposals made to improve the training and preparing of teachers.

\section{Discussion}

This research has furthered the knowledge of the memories and perceptions of the future teachers training about floods. The aims defined have been fulfilled: (1) the memories and perceptions of the teachers to teach these contents has been analysed (objectives 1 and 2); (2) the interest of the teachers in being trained to teach this risk in Social Science and/or Geography classes has been examined (objective 3); (3) the proposals made by them to improve their training and preparedness have been addressed (objective 4). The hypotheses have been partly fulfilled: with respect to the preparedness of the teachers, we have confirmed that the participants do not consider themselves to be sufficiently prepared to teach these contents to schoolchildren. This gives us cause to believe that this fact could be influenced by the training received. However, the study reveals that both those who have received training and those who have not believe themselves to have a similar level of preparedness.

In relation with the training about floods, Morote and Souto [24] indicate that only $12.1 \%$ of the future Primary Education teachers received information during their school period. Morote and Hernández [20] highlight that most of the future teachers did not receive training $(68.3 \%)$. These data contrast, for example, with other topics such as climate change. Studies such as Morote [59] show that $83.1 \%$ of trainee Primary Education teachers received training during their school years. In our study, with regard to the training received during the teachers' school years, the data indicate that the majority of the future teachers did not receive training on flood risk. In both groups (degree and MAES), those who remember having received such training represent less than $30.0 \%$.

As we have seen, at the university stage, flood risk is addressed differently depending on the discipline of the degree. The most attention to this topic is given in the Geography and History degrees, as the contents are geographical or transversal (in the case of History). However, in the Primary Education degree, the subjects on Pedagogy and those related to teaching-learning strategies are predominant. Therefore, in this degree, less attention is paid to the subjects referring to Geographical and/or Social Science content. This is giving rise to a "teaching of nothing". In other words, the students are being trained in teaching-learning strategies, but they have difficulties when implementing certain contents due to a lack of training in the different disciplines [60,61].

In relation to this issue (lack of training on flood risk), other authors have analysed which factors influence the effectiveness of the contents taught. The studies show that the use of the experimental class simulation method was more effective than the class discussion method. Azmi et al. [36] evaluate the effectiveness of knowledge transfer in disaster learning among school children by using two different learning methods with the same learning module. In their research, a total of 337 elementary school children around Klang Valley (Malaysia) were randomly recruited and grouped into experimental and control group. They conclude that the learning materials have little influence when 
implementing an effective knowledge transfer. However, awakening interest in learning was a key factor. A similar theme is analysed in the study by Ahn et al. [37], which indicates that more than $70 \%$ of teachers and students preferred experience-based learning on flood disaster safety. In addition, it highlights the importance of using the role-playing method of flood disaster to further the knowledge of students and knowing their attitudes in the face of flooding [35]. The results showed by the authors are that the use of the experimental class simulation method was more effective than the control class discussion method. The level of effectiveness of learning outcomes by using the t-test shows the average value of the control class pre-test 57.9 , and the post-test control class 67.4 based on the n-gain test the increase in learning outcomes in the control class is low with the number 0.225 .

Regarding the preparedness, studies such as Morote and Hernández [20] have also shown the low level of preparation to explain these contents in schools: the value obtained (Likert scale) was 2.9 (out of 5). It has also been found that there is no direct relationship between being prepared and having received training, as even those who had received training did not feel qualified. This highlights that the training that they received was not effective or sufficient. Similar results have been obtained in other studies, such as those by Morote and Hernández [20] and Morgan [62]. In the first study, the authors report that the respondents indicate that the instruction received was brief, superficial and based on information drawn from textbooks and emergency protocols. The results from our study show that the preparedness of teachers to explain the contents on flood risk generates average values (ranges of 2 and 3). With respect to the reasons given in their answers, in both groups the majority indicate that they had not received training or if they had, it had been insufficient. In other words, they do not feel qualified to work with these contents in the school classrooms.

This limited and non-rigorous information could lead future teachers to take the information provided in the media and use it as their own or use it as a principal source of information. This has been corroborated by Morote et al. [63] for the case of climate change. This study reveals that the majority of future teachers receive information about climate change through broadcast media and the Internet (86.2\%). Other authors also indicate an excessive use of the school textbook which, as analysed by different researchers in relation to climate change and extreme weather risks, include major errors, excessive catastrophism and are not rigorous. Moreover, they make the same errors as those made by the media [22,23,64]. As noted by Morote and Souto [24], the lack of scientific rigour of the textbooks and the absence of training received by teachers could mean that this topic is not addressed in the classroom or done so with a lack of scientific accuracy.

In relation with the interest of teach floods, it should be noted that it is endorsed by the regulatory framework. The topic of floods is compulsory in the subject of Social Science (according to the Royal Decree 126/2014 of Primary Education) and in the subject of Geography (1st cycle of Compulsory Secondary Education and the 2nd year of Baccalaureate), as stipulated by Royal Decree 1105/2014. Morote and Hernández [20], obtained that the majority of the future teachers state that it is important to teach about floods in schools (value of 4.4 in the Likert scale of 5). In our study, the participants give a high value (between 4 and 5) in response to their interest in teaching this topic in the classroom. Both the degree students and those of the MAES coincide in the reasons for their answer: to generate a "resilient" and "aware" population.

One point to consider is the transcendental role that education can play in reducing flood risk. This is contemplated as a factor that contributes to increasing resilience and reducing the vulnerability of society. The importance of education and that of raising awareness among learners about the causes and patterns of disasters has been analysed by Ahmad and Numan [30] in Bangladesh. Their study highlights that the lack of awareness of the sustainable use of natural resources has enhanced the degree and frequency of these disasters in recent decades. The research proves that the Bangladesh Open University (BOU) is a unique educational institution which, through the ODL method of teaching, using various educational media like tutorial support, printed study materials, electronic media, 
internet, cellular phone, etc. can provided a wide range of knowledge about the disaster vulnerability, risk reduction and management strategies to its learners. In relation with the work of Zhong et al. [31], the authors investigated a three-year disaster education program conducted in schools in Sichuan Province (China). From three pilot counties, the authors used stratified cluster sampling in 2016 and 2018 to separately survey the risk perceptions of 2105 children (baseline) and 1710 children (post-intervention), respectively, aged 8-12, in 45 primary schools. Zhong et al. [31] showed that the interaction effects between disaster education and parent-child interaction were statistically significant, and parent-child interaction was a moderating factor for improving risk perception (standardised indirect effect $=0.055, p<0.001$ ). These authors consider that children's flood risk perceptions can be cultivated through disaster education, which is crucial for improving disaster resilience and adaptation to climate extremes.

In Pakistan, Shah et al. [34] explain that education sector disaster resilience can be achieved through an integrated planning and implementation approach. Despite this relevance, Morote and Hernández [19] have calculated that the education factor has a global value of 3.6 (out of 5) in terms of the relevance given to it by future teachers for minimising flood risk, but it is ranked fifth of a total of 6 items. Furthermore, those who confirm that they have received training give it an even lower score (2.7). This gives cause for concern as it indicates that future teachers give a low value to the education factor to mitigate these phenomena. As indicated by Morote and Hernández [19], this may be because they consider the training received as being ineffective.

Finally, the responses obtained in this study regarding the proposals that the future teachers would implement in schools greatly coincide with those obtained by Souto et al. [65]. These researchers indicate that the majority of the proposals are related to how to address the phenomenon of flooding (emergency protocols), the analysis of past episodes and field trips. According to these authors, one aspect of these proposals that should be highlighted is that the students emphasise that these risks should be addressed from the study of the consequences (after the disaster has happened) and not so much from the point of view of their causes (climatic or human-related). According with the hypothesis, in part, they are not fulfilled: "we would expect the responses to be related to activities based on drills and talks by experts on topics not covered in the school and university curricula". Only the students of the Education Degree proposed actions related to training activities involving drills and talks by experts on the subject. This suggests that the future teachers of Primary Education regard this topic as something outside of the school context despite the considerable role that the training of the youngest cohorts can play. However, in the MAES group, the improvements proposed are related to sharing real experiences, but a considerable number of these participants also respond that they "do not know what to propose". This last response is not completely negative, as the students are in their training phase and, it shows a higher level of self-criticism than the degree students. This could be influenced by their training in different disciplines and their maturity (older age) and the fact that they are studying a specific post-graduate degree that enables them to access the professional activity.

In relation with the proposals, many studies have been carried out from the perspective of education in the USA and Europe [66,67] with a particular focus on the design of educational programmes and teaching methods [39,40,42]). According to Gary et al. [39], education is an important tool to increase the capacity of local government for community flood adaptation. With respect to the methods, Lutz [66] propose an alternative conception of risk based on evaluating participants' perceptions of their learning experiences using the analogy between playing a game of chance and living in a hazardous situation. In the Netherlands, the study by Bosschaart et al. [43] focuses on designing a flood-risk education programme to enhance the flood-risk perception of 15-year-old students. A total of 271 students participated in this study. The results of this research showed that the intervention caused increases in risk perception while perceptions of fear and trust remained the same. However, according with the authors, preparedness intentions did not change. 
In Africa, the aim of Mudavanhu [47] was to analyse schoolchildren's specific vulnerabilities to flood disasters that need to be taken into account in policy development. The author indicates that floods cause loss of learning hours, loss of qualified personnel, outbreak of waterborne diseases, high absenteeism and low syllabus coverage leading to children's poor academic performance. Besides this, the author recommends that a culture of safety be promoted through disaster education, development of good road networks and enforcement of building codes during construction of school infrastructure. In addition, in recent years, other studies have been carried out in Spain related to proposals for improvement. One of them is the incorporation of field trips. For example, Morote [52] proposes a field trip to the La Marjal Floodable Park and surrounding areas (Alicante, Spain), with the objective of teaching the youngest cohorts about the risk spaces of this coastal area and how to interpret the territory.

\section{Conclusions}

This study diagnoses the preparedness of future Primary and Secondary Education teachers to teach flood risk to schoolchildren. The findings reveal that the majority of the participants in the study did not receive training on this topic during their school and university education. However, we should point out that this training improves as students progress through their education stages, specifically for the MAES groups as they are graduates of disciplines in which this topic is usually addressed (Geography, History). The results also show that the information transmitted in the different education stages is not sufficiently effective so as to create awareness of the risk and transmit it to the students. The study finds that the future teachers finish their training without knowing how to teach these contents on flood risk. In the case of this subject, a situation arises whereby the future teachers are trained in "the teaching of nothing"; that is, they can implement many learning strategies and cognitive processes, but do not know the contents of this topic or how to teach them.

In the future, the teaching of flood risk will be contingent on: (1) the efforts of the teachers; (2) the specific training based on training courses for working teachers (CEFIREs-Centres of Training, Innovation and Resources for Teachers); and (3) the transmission of these contents based on the information provided in the school textbooks. In relation to this latter aspect, some authors have highlighted the menace of not making an appropriate selection of the contents to teach in the classroom related to natural risks and specifically floods. This is because of the lack of rigour of the majority of the textbooks when addressing climate change and atmospheric hazards and because they are influenced by the media [22,23].

With respect to the problems that need to be resolved in the teaching of atmospheric hazards and climate change, Morote and Olcina [22] explain that problems still persist due to a lack of scientific rigour in this topic because: (1) in Geography classes, the textbook continues to be the main resource used. Moreover, they are characterised by their limited scientific rigour and being notably influenced by the media and by excessive catastrophism when analysing this topic; (2) the media notably influences teachers' conceptions of information on climate change; and (3) teacher training in this topic is limited.

With regard to the proposals for improvement, one of the features that define the participants of the MAES, in comparison with what is learned in the Education degree, is their low level of pedagogic training but their high-level general training in a specific discipline. This has influenced some of the proposals such as the resources related to real experiences or responses about not knowing what to propose. We can also observe that in this group no proposals were made related to drills or talks by experts. This could be a positive response in the sense that, as future teachers they regard themselves prepared to carry out these tasks in the future, although they lack training. On the contrary, these types of responses (talks by experts, the viewing of documentaries, etc.), are usually proposed by the students of the Primary Education degree as they do not feel enough prepared to address such specific topics related to Geography [65]. 
Now that these results are known, the universities should implement different action measures in order to improve the training since: (1) the current educational legislation establishes it; (2) it is a priority topic that will become even more prominent, according to the climate change scenarios; and (3) not being prepared usually leads to the recurrent use of the textbook which, as we have seen, is not usually the best source for training in these issues of climate change and associated risks.

To improve the knowledge of the training about floods it is necessary take into account different actions. Firstly, teaching with the "OIL" proposals ("Imagination" plus "Originality" and taking in to account the "Local territory") [23]. This causes the student's motivation to learn to increase. Secondly, teaching taking in to account the vulnerability factor. We can see, recently, some examples in central Europe and Asia with the floods with hundreds of fatalities due to the increase of the urbanisation and population (increase of the exposure), and without forgetting climate change. For decades, different authors have been highlighting how today's society is a society at risk $[68,69])$. Authors such as White [70] note that without humans there is no risk. Therefore, when the concept is taught, it should take into account the human factor. Wisner et al. [71] argue that the risk equation (R) is composed of: (1) the physical factor or hazard (P); and (2) the human factor (vulnerability) (V) $(\mathrm{R}=\mathrm{P} \cdot \mathrm{V})$. As well as including the vulnerability factor in the human variable, other authors [72] also incorporate exposure, which is important for generating risk maps.

Thirdly, the importance of the correct explanation of the cold front. For example, in the school textbooks, as an explanatory factor of flooding, it rightly states that it is generated by the cold front phenomenon, but with no further explanation or illustrative images such as a satellite image [22]. In order to explain how a cold front results in an event of heavy rains, four factors must be mentioned: (1) the jet stream undergoes a rupture that isolates a small portion of cold air from the general circulation, placing it in clearly warmer environments; (2) areas near the Mediterranean Sea-in the late summer months, the seawater has high temperatures, and this high temperature facilitates a high evaporation and the accumulation of vapour in the atmosphere; (3) surface wind circulation between the sea and the coastal areas (easterly winds in the Mediterranean region) that lead the humid air to move from the sea to land; and (4) importance of the orographic factor (mountains near the coast) since it forces the air to rise, thereby cooling it and, reaching the dew point, it starts to rain. This would be a simple explanation of the operation of the atmospheric factor (the rain episode) that should be inserted, with the use of figures and diagrams, in the analysed topics on Climatology.

Therefore, this poses a considerable challenge in the Spanish education system to improve the preparedness of future teachers who, in short, will be those who train and raise awareness among the new generations about this global phenomenon. As a limitation of this research, however, we should indicate that the small number of Geography students has prevented us from carrying out a more detailed analysis in this study that would allow us to confirm whether there are differences both in the training and in the proposals. This constitutes a challenge for future research. A second challenge would be to analyse how floods are explained in schools based on surveys and interviews with active teachers.

To conclude, we should emphasise that education is a fundamental pillar when contemplating the vulnerability factor as a better-trained and more aware society with respect to risks can be even more valuable that certain structural mitigation factors (infrastructures, etc.). However, as the results of this study show, there is still a lot of ground to be covered in the field of education so that it may become an essential tool to generate a society that is more resilient to climate change [26-28].

Author Contributions: Conceptualization, methodology, formal review, and investigation, Á.-F.M., M.H. and J.O. All authors have read and agreed to the published version of the manuscript.

Funding: The results presented in this article are part of the research project "Social representations of school content in the development of teaching competencies" funded by the Spanish MINECO under grant number PGC2018-094491-B-C32 and co-financed with EU FEDER funds. 
Institutional Review Board Statement: Not applicable.

Informed Consent Statement: Informed consent was obtained from all subjects involved in the study.

Data Availability Statement: The data presented in this study are available in [Are Future School Teachers Qualified to Teach Flood Risk? An Approach from the Geography Discipline in the Context of Climate Chang].

Conflicts of Interest: The authors declare no conflict of interest.

\section{References}

1. Pérez-Morales, A.P.; Gil, S.; Quesada, A. ¿Somos todos iguales ante una inundación? Análisis de la vulnerabilidad social en el litoral mediterráneo. Boletín De La Asoc. De Geógrafos Españoles 2021, 10-22. [CrossRef]

2. Intergovernmental Panel on Climate Change (IPCC). Special Report Global Warming of $1.5^{\circ} \mathrm{C}$. 2018. Available online: https: //www.ipcc.ch/report/sr15/ (accessed on 5 July 2021).

3. Mann, M.E.; Rahmstorf, S.; Kornhuber, K.; Steinman, B.A.; Miller, S.K.; Petri, S.; Coumou, D. Projected changes in persistent extreme summer weather events: The role of quasi-resonant amplification. Sci. Adv. 2018, 4, eaat3272. [CrossRef]

4. Muñoz, C.; Schultz, D.; Vaughan, G. A midlatitude climatology and interannual variability of 200- and 500-hPa cut-off lows. J. Clim. 2020, 33, 2201-2222. [CrossRef]

5. Serrano, R. Reconstrucción Climática Instrumental de la Precipitación diaria en España: Ensayo Metodológico y Aplicaciones. Ph.D. Thesis, Universidad de Zaragoza, Zaragoza, Spain, 2017.

6. Woollings, T. A Battle for the Jet Stream is Raging above Our Heads. The Conversation. 14 November 2019. Available online: https:/ / theconversation.com/a-battle-for-the-jet-stream-is-raging-above-our-heads-125906 (accessed on 5 July 2021).

7. Centros de Estudios y Experimentación de Obras Públicas (CEDEX). Evaluación Del Impacto Del Cambio Climático En Los Recursos Hídricos y Sequías En españa; Ministerio de Agricultura y Pesca, Alimentación y Medio Ambiente y Ministerio de Fomento: Madrid, Spain, 2017.

8. De Luis, M.; Brunetti, M.; González-Hidalgo, J.C.; Longares, L.A.; Martin-Vide, J. Changes in seasonal precipitation in the Iberian Peninsula during 1946-2005. Glob. Planet. Chang. 2010, 74, 27-33. [CrossRef]

9. Reliefweb. Natural Disasters. 2019. Available online: https://reliefweb.int/report/world/natural-disasters-2019 (accessed on 5 July 2021).

10. Intergovernmental Panel on Climate Change (IPCC). Climate Change 2013 and Climate Change. 2014. Available online: http:/ / www.ipcc.ch (accessed on 5 July 2021).

11. EM-DAT EM-DAT Query Tool. The International Disasters Database. Centre for Research on the Epidemiology of Disasters (CRED). Available online: https:/ / public.emdat.be/ data (accessed on 5 July 2021).

12. Ministerio del Interior. Anuario del Ministerio del Interior. 2020. Available online: http://www.interior.gob.es/documents/6423 17/1204854/Anuario+Estad\%C3\%ADstico+del+Ministerio+del+Interior+2019/81537fe0-6aef-437a-8aac-81f1bf83af1a (accessed on 5 July 2021).

13. Olcina, J. Verdades y mentiras sobre el riesgo de inundaciones en el litoral mediterráneo: Balance de medio siglo. In Proceedings of the Jornada Sobre Fenómenos Meteorológicos Extremos en el Mediterráneo, Valencia, Spain, 11 December 2018.

14. Ministerio para la Transición Ecológica. Gestión de Los Riesgos de Inundación. 2019. Available online: https://www.miteco.gob. es/es/agua/temas/gestion-de-los-riesgos-de-inundacion/ (accessed on 5 July 2021).

15. Plan de Acción Territorial Sobre Prevención del Riesgo de Inundación en la Comunitat Valenciana (PATRICOVA). Documentation del PATRICOVA. 2015. Available online: http://www.habitatge.gva.es/es/web/planificacion-territorial-e-infraestructuraverde/patricova-docs (accessed on 5 July 2021).

16. Join Research Center. Atlas of the human planet 2017. In Global Exposure to Natural Hazards. European Commission; DG Join Research Center: Ispra, Italy, 2017.

17. Olcina, J.; Saurí, D.; Hernández, M.; Ribas, A. Flood policy in Spain: A review for the period 1983-2013. Disaster Prev. Manag. Int. J. 2016, 25, 41-58. [CrossRef]

18. Parker, D.J. Floodplain development policy in England and Wales. Appl. Geogr. 1995, 15, 341-363. [CrossRef]

19. Morote, A.F.; Hernández, M. Social representations of flooding of future teachers of primary education (social sciences): A geographical approach in the Spanish mediterranean region. Sustainability 2020, 12, 6065. [CrossRef]

20. Morote, A.F.; Hernández, M. Water and flood adaptation education: From theory to practice. Water Prod. J. 2021, 1, 31-40. [CrossRef]

21. Perles, M.J.; Sortino, J.F.; Cantarero, F.J. Cartografía de la vulnerabilidad del territorio frente al riesgo de inundación. Propuesta adaptada a la directive europea de inudaciones y normativas derivadas. Boletín De La Asoc. De Geográfos Españoles 2017, 75, 341-372.

22. Morote, A.F.; Olcina, J. El estudio del cambio climático en la educación primaria: Una exploración a partir de los manuales escolares de ciencias sociales de la comunidad valenciana. Cuad. Geográficos 2020, 59, 158-177. [CrossRef]

23. Morote, A.F.; Olcina, J. Cambio climático y sostenibilidad en la educación primaria. Problemática y soluciones que proponen los manuales escolares de Ciencias Sociales. Sosten. Econ. Soc. Ambient. 2021, 3, 25-43. [CrossRef]

24. Morote, A.F.; Souto, X.M. Educar para convivir con el riesgo de inundación. Estud. Geogr. 2020, 81, 1-14. [CrossRef] 
25. Bello, L.; Cruz, G.E.; Meira, P.A.; González, E. El cambio climático en el bachillerato: Aportes pedagógicos para su abordaje. Enseñanza De Las Cienc. Rev. De Investig. Exp. Didácticas 2021, 39, 137-156.

26. Caride, J.A.; Cartea, P.A.M. Educación, ética y cambio climático. Innovación Educ. 2019, 29, 61-76. [CrossRef]

27. González, E.; Meira, P.A.; Gutiérrez, J. ¿Cómo educar sobre la complejidad de la crisis climática? Hacia un currículum de emergencia. Rev. Mex. De Investig. Educ. 2020, 25, 843-872.

28. Gutiérrez, J.; Meira, P.A.; González, E. Educación y comunicación para el cambio climático. Rev. Mex. De Investig. Educ. 2020, 25, 819-842.

29. Organización de las Naciones Unidas (ONU). Sustainable Development Goals. 2015. UNDP, Sustainable Development Agenda. Available online: https://www.undp.org/content/undp/es/home/sustainable-development-goals/resources.html (accessed on 5 July 2021).

30. Ahmad, S.; Numan, S.M. Potentiality of disaster management education through open and distance learning system in Bangladesh Open University. Turk. Online J. Distance Educ. 2015, 16, 249-260. [CrossRef]

31. Zhong, S.; Cheng, Q.; Zhang, S.; Huang, C.; Wang, Z. An impact assessment of disaster education on children's flood risk perceptions in China: Policy implications for adaptation to climate extremes. Sci. Total Environ. 2021, 757, 143761. [CrossRef]

32. Mohammad, W.M.Z.; Wan Mansor, W.N.A.; A Hamid, N.A.; Sukeri, S.; Hasan, H.; Yeong Yeh, L.; Muhd Besari, A.; Draman, N.; Zakaria, R.; Zeehaida, M. Effectiveness of community-based health education on preparedness for flood-related communicable diseases in kelantan. Malays. J. Public Health Med. 2020, 20, 117-124. [CrossRef]

33. Robiansyah, I.E.; Mudjito; Yuliyati; Atiqoh. Developing interactive multimedia Flood Prevention Education (FPE) on disaster risk reduction learning for students with hearing impairment in special school. In Proceedings of the 2019 5th International Conference on Education and Technology, ICET, Seoul, Korea, 27-29 May 2019; pp. 135-138.

34. Shah, A.A.; Gong, Z.; Ali, M.; Jamshed, A.; Naqvi, S.A.A.; Naz, S. Measuring education sector resilience in the face of flood disasters in Pakistan: An index-based approach. Environ. Sci. Pollut. Res. 2020, 27, 44106-44122. [CrossRef] [PubMed]

35. Abied, H.; Suharini, E.; Kurniawan, E. The effectiveness of role-playing simulation method in flood disaster education for social science learning. J. Crit. Rev. 2020, 7, 496-503.

36. Azmi, E.S.; Rahman, H.A.; How, V. A two-way interactive teaching-learning process to implement flood disaster education in an early age: The role of learning materials. Malays. J. Med. Health Sci. 2020, 16, 166-174.

37. Ahn, Y.-M.; Hong, W.-H.; Lee, H.-K.; Bae, Y.-H. An awareness and needs analysis for the flood disaster school safety education execution-focusing on the awareness of secondary school students and teachers in daegu. J. Archit. Inst. Korea 2020, 36, 13-22.

38. Madhuri, T.H.R.; Bhowmick, P.K.; McCormick, M. Roles of government and community support, flood experience, and flood education in livelihood resilience. J. Sociol. Soc. Welf. 2015, 42, 101-133.

39. Gary, G.; Allred, S.; Lo Giudice, E. An extension education program to help local governments with flood adaptation. J. Ext. 2014, 52, n4.

40. Lee, Y.; Kothuis, B.B.; Sebastian, A.; Brody, S. Design of transformative education and authentic learning projects: Experiences and lessons learned from an international multidisciplinary research and education program on flood risk reduction. In Proceedings of the ASEE Annual Conference and Exposition, Tampa, FL, USA, 15 June 2019.

41. McEwen, L.; Stokes, A.; Crowley, K.; Roberts, C. Using role-play for expert science communication with professional stakeholders in flood risk management. J. Geogr. High. Educ. 2014, 38, 277-300. [CrossRef]

42. Williams, S.; McEwen, L.J.; Quinn, N. As the climate changes: Intergenerational action-based learning in relation to flood education. J. Environ. Educ. 2017, 48, 154-171. [CrossRef]

43. Bosschaart, A.; Van der Schee, J.; Kuiper, W. Designing a flood-risk education program in the Netherlands. J. Environ. Educ. 2016, 47, 271-286. [CrossRef]

44. Lechowicz, M.; Nowacki, T. School education as an element of natural disaster risk reduction. Pr. i Studia Geogr. 2014, 55, 85-95.

45. Bricelj, M. Kranjska stena-An example of good school practice. Geogr. V Soli 2013, 22, 51-56.

46. Kovacs, A.; Ştefănie, H.; Botezan, C.; Crăciun, I.; Ozunu, A. Assesment of natural hazards in european countries with impact on young people. Int. Multidiscip. Sci. GeoConference Surv. Geol. Min. Ecol. Manag. SGEM 2017, 17, 73-80.

47. Mudavanhu, C. The impact of flood disasters on child education in Muzarabani District, Zimbabwe. Jamba J. Disaster Risk Stud. 2015, 6, 138. [CrossRef]

48. Bach, J. El riesgo de inundación: Una propuesta de tratamiento. Rev. Alambique 2008, 55, 43-55.

49. Díez-Herrero, A. Buscando riadas en los árboles: Dendrogeomorfología. Enseñanza De Las Cienc. De La Tierra 2015, $23,272-285$.

50. Marqués, M.A. Las inundaciones, caso práctico. In Terc. Jornades Del CRECIT: La Didáctica De Los Riesgos Nat; Institut d’Estudis Andorrans: Sant Julià de Lòria, Andorra, 2005.

51. Cuello, A. Las Inundaciones del invierno 2009-2010 en la prensa, un recurso educativo para las ciencias sociales. Rev. De Investig. En Didáctica De Las Cienc. Soc. 2018, 2, 70-87.

52. Morote, A.F. El parque inundable la marjal de alicante (españa) como propuesta didáctica para la interpretación de los espacios de riesgo de inundación. Didáctica Geográfica 2017, 18, 211-230.

53. Morote, A.F.; Pérez, A. La comprensión del riesgo de inundación a través del trabajo de campo: Una experiencia didáctica en San Vicente del Raspeig (Alicante). Vegueta. Anu. De La Fac. De Geogr. E Hist. 2019, 19, 609-631.

54. Universidad de Valencia. Anuario Estadístico. 2021. Available online: https://webges.uv.es/MS10/servlet/.mstrWeb?evt=3010 \&Server=MSTRATEGY\&Project=RECULL\& (accessed on 21 March 2020). 
55. Pérez-Gil, J.; Moscoso, S.; Rodríguez, R. Validez de constructo: El uso del análisis factorial exploratorio-confirmatorio para obtener evidencia de validez. Psicothema 2000, 12, 442-446.

56. Satorra, A.; Bentler, P.M. Ensuring positiveness of the scaled difference Chi-Square test statistic. Psychometrika 2010, 75, 243-248. [CrossRef]

57. Sharpe, D. Chi-Square test is statistically significant: Now what? Pract. Assess. Res. Eval. 2015, 20, 8. [CrossRef]

58. Moreno-Vera, J.R.; Ponsoda, S.; López-Fernández, J.A.; Blanes-Mora, R. Holistic or traditional conceptions of heritage among early-childhood and primary trainee teachers. Sustanability 2020, 12, 8921. [CrossRef]

59. Morote, A.F. La responsabilidad en la reducción de la vulnerabilidad frente a los riegos de inundación. El papel de la escuela y la formación del profesorado. In Proceedings of the XI Congreso Ibérico de Gestión y Planificación del Agua, Fundación Nueva Cultura del Agua (FNCA), Zaragoza, Spain, 3-9 September 2020; pp. 910-920.

60. Gómez-Carrasco, C.J.; Martínez-Miralles, P.; López-Facal, R. Handbook of Research on Teacher Education in History and Geography; Peter Lang Publishing: Berlín, Germany, 2021.

61. Parra, D.; Morote, A.F. Memoria escolar y conocimientos didáctico-disciplinares en la representación de la educación geográfica e histórica del profesorado en formación. Rev. Interuniv. Form. Profr. 2020, 95, 11-32. [CrossRef]

62. Morgan, A. Me as a science teacher': Responding to a small network survey to assist teachers with subject-specific literacy demands in the middle years of schooling. Aust. J. Teach. Educ. 2012, 37, 73-95. [CrossRef]

63. Morote, A.F.; Campo, B.; Colomer, J.C. Percepción del cambio climático en alumnado de $4^{\circ}$ del grado en educación primaria (Universidad de Valencia, España) a partir de la información de los medios de comunicación. Rev. Electrónica Interuniv. Form. Profr. 2021, 24, 131-144. [CrossRef]

64. Olcina, J. La enseñanza del tiempo atmosférico y del clima en los niveles educativos no universitarios. Propuestas didácticas. In Enseñanza y Aprendizaje de la Geografía para el Siglo XXI; Sebastiá, R., Tonda, E.M., Eds.; Servicio de Publicaciones: Alicante, Spain, 2017; pp. 119-148.

65. Souto, X.M.; Morote, A.F.; García, D. Crisis y riesgos naturales en la educación social. El caso del riesgo de inundación en Educación Primaria. In Crisis y Espacios de Oportunidad; Retos para la Geografía; AGE y Universidad de Valencia: Valencia, España, 2019; pp. 171-185.

66. Lutz, T. Toward a new conceptual framework for teaching about flood risk in introductory geoscience courses. J. Geosci. Educ. 2011, 59, 5-12. [CrossRef]

67. McWhirter, N.; Shealy, T. Case-based flipped classroom approach to teach sustainable infrastructure and decision-making. Int. J. Constr. Educ. Res. 2018, 16, 1-21. [CrossRef]

68. Adam, B.; Beck, U.; Van Loon, J. The Risk Society and Beyond: Critical Issues for Social Theory; Sage: Thousand Oaks, CA, USA, 2000.

69. Giddens, A. El Capitalismo y la Moderna Teoría Social; Labor reed: Barcelona, Spain, 1977.

70. White, G.F. Natural Hazards, Local, National, Global; Oxford University Press: London, UK, 1974.

71. Wisner, B.; Blaikie, P.; Cannon, T.; Davis, I. At Risk. Natural Hazards, People's Vulnerability, and Disasters; Routledge: London, UK, 2004.

72. Ward, P.J.; Blauhut, V.; Bloemendaal, N.; Daniell, J.E.; De Ruiter, M.C.; Duncan, M.J.; Emberson, R.; Jenkins, S.F.; Kirschbaum, D.; Kunz, M.; et al. Review article: Natural hazard risk assessments at the global scale. Nat. Hazards Earth Syst. Sci. 2020, 20, $1069-1096$. [CrossRef] 